\title{
8
}

\section{Domestic Political Reforms and China's Diplomacy in the Pacific: The Case of Foreign Aid}

Denghua Zhang

\section{Introduction}

China's rise in the Pacific ${ }^{1}$ is in the spotlight and provoking growing concern from traditional powers. Beijing has substantially increased its engagement with the region since 2006. Chinese President Xi Jinping paid his first official visit to Papua New Guinea (PNG) in November 2018. On the sidelines of APEC held in Port Moresby, he also met with leaders of the eight Pacific Island countries (PICs) that have diplomatic relations with China. The leaders agreed to elevate the China-PICs relationship to a comprehensive strategic partnership of mutual respect and common development (China MFA 2018), although China uses this term loosely in diplomacy and the meaning remains ambiguous. To push back against China's influence in the region, US Vice President Mike Pence announced at the APEC CEO summit that the US would partner with Australia and PNG to develop Lombrum Naval Base on PNG's Manus Island and

1 In this chapter, the Pacific region refers to the 14 Pacific sovereign states. 
jointly 'protect sovereignty and maritime rights of the Pacific Islands' (Pence 2018). Competition between China and traditional powers will most likely continue and intensify in the Pacific.

At the domestic level, the Xi Jinping administration has been conducting political reforms that could have a significant impact on China's engagement with other countries including Pacific Island states. China's diplomacy is becoming more proactive and assertive. Since March 2018, Beijing has been implementing a new round of government restructuring, much of which is closely linked to its diplomacy. For example, in April 2018 China established its first stand-alone aid agency: the China International Development Cooperation Agency (CIDCA). This vice-ministerial organisation, designed to strengthen the planning and monitoring of Chinese aid, has been placed under the supervision of top Chinese diplomats Yang Jiechi and Wang Yi. In addition, the Office of Overseas Chinese Affairs under the State Council, which is responsible for liaising with the Chinese diaspora, has been merged into the United Front Work Department, a powerful organisation of the Chinese Communist Party.

This chapter aims to add a new perspective to the literature on China in the Pacific. By adopting Anthony Giddens' theory of structuration on structure and agency, the chapter aims to analyse how China's recent domestic political reforms will affect its engagement with PICs, which is rarely touched on in the literature. As foreign aid is a crucial element of China's growing outreach in the Pacific and has been in the spotlight due to accusations such as ineffectiveness and the use of debt-for-equity swaps, this chapter will examine three questions through the prism of Chinese foreign aid: (1) What are China's national interests in the Pacific? (2) How have China's evolving national interests guided various Chinese actors' work on aid and informed structure changes? (3) In what ways have these actors reshaped China's national interests and the bureaucratic structure? The impact of CIDCA on China's aid program in the Pacific will be included in the discussion. I will argue that different Chinese actors have been involved in a fierce competition for influence in decision-making on aid, and that diplomacy will have more weight in a CIDCA-led Chinese aid system - with a consequent impact on the Pacific region. 


\section{Structure and agency theory}

The relationship between structure and agent is a recurrent theme in social sciences. According to the theory of structuration developed in the 1980s by Anthony Giddens, a prominent British sociologist, structure refers generally to rules and resources, and agency is defined as actors' capability to do things in the first place $(1984: 9,24)$. The constitution of agents and structures represent a duality as structure is both constraining and enabling, while the activities of agents constitute and reconstitute social systems (ibid.:25). Constructivists in international relations take the discussion further. For example, Alexander Wendt argues that structure is not static and predetermined but subject to actors' mutual interaction (1992).

Based on Giddens' theory of structuration, a state's national interests inform the creation of its norms and allocation of resources, and form the bureaucratic structure. The bureaucratic structure conditions the actions of actors. However, purposeful actors are not passive but active. They use their agency to alter the state's national interests and transform/reshape the structure. It is noteworthy that the structuration theory is not without criticism, such as it is an analytical rather than substantive theory and does not generate hypothesis (Wendt 1987). This chapter does not intend to engage in these debates or make theoretical contributions, but rather aims to use Giddens' theory as a new approach to analyse China's diplomacy and aid program in the Pacific. Data sources for the research comprise existing scholarly works, interviews and the author's own observation of China-PICs relations as a researcher and former practitioner.

\section{China's national interests in the Pacific}

Pacific states are not in the top tier of China's foreign policy agenda. Chinese diplomats categorise the Pacific as part of the broad developing world that China is keen to align with. To be more specific, Pacific states are referred to as part of China's 'greater periphery' (da zhoubian, 大周边), a term first used loosely to label China's neighbouring Asian countries and then extended to include the Pacific (Zhang 2017:45). Nonetheless, China's national interests in the Pacific region are multifaceted and evolving.

The diplomatic competition between China (referred to as the People's Republic of China (PRC) or mainland China in China's official discourses) and Taiwan (or the Republic of China) has dominated China's diplomacy 
in the Pacific. The Chinese Government defines it as an issue of paramount importance to China's territorial integrity and national reunification (Yang 2011). Obtaining Pacific states' support of the One China policy has remained a central task of the Chinese Government since the 1970s when China started to establish official relations with Pacific states such as Fiji and Samoa. Although most of the 14 sovereign Pacific countries are small states and have limited influence in international affairs, they have an equal vote to large states at the UN. Most Pacific states are also highly dependent on foreign aid. These two factors have made PICs important players that both China and Taiwan try to court in the diplomatic wrestling. As Table 1 shows, this battle has been tense and some Pacific states have switched their positions back and forth but, globally, the number of Taiwan's diplomatic allies is decreasing. Since February 2016, another eight countries (Gambia, Sao Tome and Principe, Panama, the Dominican Republic, Burkina Faso, El Salvador, Solomon Islands and Kiribati) moved their recognition to China, reducing Taiwan's diplomatic allies to 15. Among them, four were from the Pacific; the sheer number of PICs now supporting China gives the Pacific region more importance in China's diplomatic competition with Taiwan in the future.

Table 1. Diplomatic landscape for China and Taiwan in the Pacific

\begin{tabular}{|c|c|c|c|c|}
\hline Pacific country & Taiwan & PRC & Taiwan & PRC \\
\hline Fiji & & 5 Nov. 1975 & & \\
\hline Samoa & 29 May 1972 & 6 Nov. 1975 & & \\
\hline PNG & & 12 Oct. 1976 & 5 July 1999 & 21 July 1999 \\
\hline Vanuatu & & 26 Mar. 1982 & 3 Nov. 2004 & 11 Nov. 2004 \\
\hline $\begin{array}{l}\text { Federated States } \\
\text { of Micronesia }\end{array}$ & & 11 Sept. 1989 & & \\
\hline Cook Islands & & 25 July 1997 & & \\
\hline Tonga & 10 Apr. 1972 & 2 Nov. 1998 & & \\
\hline Niue & & 12 Dec. 2007 & & \\
\hline Solomon Islands & 24 Mar. 1983 & 21 Sept. 2019 & & \\
\hline Kiribati & & 25 June 1980 & 7 Nov. 2003 & 27 Sept. 2019 \\
\hline \multicolumn{5}{|c|}{ Pacific states that recognise Taiwan } \\
\hline Tuvalu & 19 Sept. 1979 & & & \\
\hline Nauru & 4 May 1980 & 21 July 2002 & 14 May 2005 & \\
\hline Palau & & & 29 Dec. 1999 & \\
\hline Marshall Islands & & 16 Nov. 1990 & 20 Nov. 1998 & \\
\hline
\end{tabular}

Source: Compiled by author. 
More broadly, it is wise to position the Pacific states in China's overall diplomacy towards the developing world (Wesley-Smith 2013). The huge differences in political systems and values and the 'century of humiliation' (1840-1949) have made the Chinese Government distrustful of developed countries at a deep level and created a strong sense of insecurity (Callahan 2012; Gries 2004), which forced China to seek support from developing countries. The need to develop a unifying identity with other developing countries has been a fundamental principle in China's foreign policy since the establishment of the PRC by the Communist Party in 1949. Beijing believes that the common identity of being developing countries and a shared history of being victims of colonisation will draw China and these countries together. China also considers developing countries to be a reliable resource that China can call upon for support when needed, such as the PRC's admission to the UN Security Council in November 1971 and after Tiananmen Square in 1989 when developed countries imposed sanctions on China. This strategy is a crucial reason why China sticks firmly to its identity as a developing country despite the fact that it is now the world's second largest economy and the largest emerging donor. It also explains why Chinese leaders have repeatedly highlighted that 'both China and Pacific island countries are developing countries' in meetings with their counterparts from the Pacific. In a recent example, in his group meeting in November 2018 in Port Moresby with the leaders of the then eight PICs that had diplomatic relations with China, Xi Jinping began by emphasising that 'China and Pacific island countries are all developing countries in the Asia Pacific region, they have been good friends ... good partners ... and good brothers' (China MFA 2018). Relations with Pacific states also enables China to demonstrate that big and small countries are equal partners. China has lavished red-carpet treatment on Pacific leaders during their visits to China.

Guided by this policy of fostering closer relations with developing countries, China has intensified its engagement with the military government in Fiji since the coup in 2006 while the latter was under severe sanctions from traditional powers, especially Australia and New Zealand. Fiji has become the regional hub and one of China's main diplomatic, trade and aid partners in the region. In February 2009, when he was China's vice president, Xi Jinping paid a stopover visit to Fiji despite open opposition from Australia and New Zealand. China has also substantially increased its assistance and financial support to Fiji. As the Lowy Institute (2019) in Sydney estimates, between 2011 and 2017, China's total aid committed 
and spent in Fiji exceeded US\$379.2 million and US\$316.7 million respectively, making China the second largest donor behind Australia. ${ }^{2}$ Chinese ambassadors dispatched to Fiji are more seasoned career diplomats compared with those assigned to other Pacific states.

China's economic interest in the Pacific region is minimal in the context of its overall global trade. In 2017, China's exports to and imports from the 14 PICs, as well as French Polynesia and New Caledonia, constituted 0.21 per cent and 0.19 per cent of China's global merchandise trade (Pacific Trade and Investment Office 2018:5). China’s economic activities have largely focused on extractive industries in resources-rich PICs, with the PNG Ramu nickel mine China's largest single investment in the region (US $\$ 1.4$ billion). In 2017, fuels represented 43.4 per cent of China's imports from PNG and 25.8 per cent of China's total imports from the region (ibid.:3-4). Since December 2014, China has committed to purchasing 2 million tonnes of PNG liquefied natural gas (worth US\$1 billion) per annum for 20 years. In 2017, China also imported wood products from Solomon Islands to the value of US\$483.2 million, accounting for 13.9 per cent of China's total imports from the Pacific (ibid.).

China's military ambitions in the Pacific are limited at present but may grow in the near future. Using the 'three island chains' theory adopted by China's People's Liberation Army Navy (PLAN) as the benchmarkalthough Chinese interpretations are diverse and multifaceted (Erickson and Wuthnow 2016; Pedrozo 2010)—the Pacific region is an important part of the second and third island chains. At present, China's PLAN has been preoccupied with maritime disputes along the first island chain in the South and East China seas and it has not given much attention to the Pacific. PLAN's engagement with PICs is still superficial, consisting of donations of non-combatant vehicles and uniforms, construction/upgrade of military hospitals and visits from PLAN medical ships (the Peace Ark). However, there are signs that things are changing and that the Pacific may occupy a more significant position in China's military strategies. Since Xi Jinping took power in 2013, the Chinese Government has apparently started to move away from 'hiding the capacity and keeping a low profile' (taoguang yanghui, 蹈光养晦), a principle that had guided China's diplomacy since the 1990s. China's diplomacy has become more

2 Over the same period, Australian total aid committed and spent in Fiji was about US\$551.8 million and US\$408.5 million respectively. 
ambitious and assertive (Brady 2017:239-40). China PLAN has also stepped up efforts to move from a green-water navy to a blue-water navy with notable progress. It has had two aircraft carriers constructed and a third is under way. In April 2018, President Xi Jinping, who is also Chairman of the Central Military Commission, reviewed China's PLAN in the South China Sea, the largest of its kind in PLAN history. He called on PLAN to build a 'world first-class navy'. PLAN leadership's response to this call casts some light on their strategic thinking:

From the geo-strategic perspective, China is placed in a disadvantaged oceanic environment, with coastal waters semienclosed and separated by island chains, and access to the sea blocked by other powers ... Our country has entered into a crucial stage of moving from a land power to both a land and sea power ... PLAN is the most appropriate and needed strategic force within PLA to go global (zou chuqu) (PLAN Party Committee 2018).

With increased long-range projection capabilities and heightened USChina strategic competition in the Indo-Pacific region, it is likely that PLAN will develop substantial engagement with Pacific states in the future. However, whether and to what extent China can successfully build a closer strategic and defence relationship with these Pacific states is questionable. The 2018 announcement by the US to build the Lombrum Naval Base in PNG with Australia and PNG, and speculation around China's intention to build a naval base in Vanuatu, reveal traditional powers' growing concerns about China's military ambitions in the Pacific.

China's diaspora might be caught in social unrest in some Pacific countries in the future. If this happens, it is more likely that China would arrange charter flights rather than use military forces to evacuate affected Chinese citizens. The Chinese Government adopted this approach during the riots in Solomon Islands and Tonga in 2006. Compared with Africa and Asia, Chinese diaspora and companies, especially state-owned enterprises, in the Pacific are much smaller in number.

\section{The role of structure}

The first half of this section will examine how China's national interests in the Pacific have shaped its bureaucratic structure for foreign aid work in the region. The second half discusses some new changes, especially CIDCA's impact on Chinese aid in the Pacific. 
Chinese aid to Pacific states consists of grants, interest-free loans and concessional loans. Before the establishment of CIDCA, the Ministry of Commerce (MOFCOM) managed grants and interest-free loans. The China Export-Import Bank (Exim Bank) managed concessional loans, subject to the approval of MOFCOM as the supervisor. Established in 1994 as a vice-ministerial level agency, China Exim Bank is the only policy bank to provide concessional loans and has about 600 staff. The Corporate Business Department, which is in charge of commercial loans and especially export buyers' credits, and the Concessional Loan Department are the two most important sections of the bank and each has about 100 staff. $^{3}$

When MOFCOM was in charge of Chinese aid, the State Council required that it consult China's Ministry of Foreign Affairs (MFA) on aid allocation. MFA is responsible for China's bilateral relations with partner countries including in the Pacific. Based on the needs of China's diplomacy, MFA provided advice to MOFCOM on whether China should provide aid to the targeted recipient country. To secure diplomatic support from Pacific states on the One China policy, MFA encouraged MOFCOM to deliver more aid to the region, as well as favouring debt relief ${ }^{4}$ for Pacific states. About five to six officials in the Division of South Pacific and Canada under MFA's Department of North American and Oceanian Affairs manage China's bilateral relations with the Pacific.

Provincial-level aid complements Chinese aid from the central government to the Pacific. In recognition of its close diaspora links with the Pacific, Guangdong Province is tasked with engaging Pacific states and providing provincial-level aid. The vast majority of Chinese diaspora in Fiji and Samoa are from this province and, in recent years, Guangdong's engagement with PICs has increased. The main activities include shortterm medical tours (song yi shang dao, 送医上岛) and visits by acrobaticl arts troupes for celebrations. The medical tour program started in 2012. It consists of medical specialists of different types selected from hospitals in Guangdong and are led by a senior official from the foreign affairs office or health department of the province. Between 2012 and 2016, the medical tours went to all eight Pacific states with diplomatic relations with China, except Niue (Wang and Yu 2017:201-03).

3 Former China Exim Bank official, July 2018. Interview with author.

4 Debt relief means partial or total remission of debt. 
Given the critical importance of decreasing Taiwan's influence in the Pacific, foreign aid is the main component of China's engagement with Pacific states. As noted earlier, MOFCOM had been China's central organisation tasked with managing foreign aid until the establishment of CIDCA in April 2018. MOFCOM's Department of Foreign Aid, and more specifically the Division of South Pacific, was responsible for Chinese aid to Pacific states. Within this department, three divisions focused on Africa, two divisions worked on Asia while one each managed Chinese aid in West Africa, North Africa and Europe, Latin America and South Pacific (China MOFCOM 2015). This structure alone is a telling sign that Africa and Asia receive most of China's attention in the area of aid; the Pacific does not receive particular attention.

By providing aid to Pacific states, the Chinese Government also aims to safeguard its growing economic interests in the region. A good bilateral relationship provides a supportive environment for Chinese trade and investment activities in these countries. Moreover, the agreements for Chinese concessional loans require that the project be awarded to Chinese contractors, especially state-owned enterprises. This is a crucial step for Chinese companies to establish themselves in the Pacific market, which is new to them, before they move on to commercial projects.

Military aid is a key tool for China to strengthen military ties with counterparts in the region and protect its strategic interests, which are likely to grow in the near future. Similar to Chinese military aid to other regions, the PLA manages the budget for Chinese military aid to the Pacific and is deliberately non-transparent. It is even more opaque than Chinese aid managed by MOFCOM. Although China's current military aid to PICs is limited in value and scope, Chinese universities are training military officers from the region through scholarship programs and shortterm training. For example, in September 2018, Esita Batiniqila became the first female officer from the Fiji Navy to be awarded a four-year Chinese scholarship to study navy ship service command and navy military science at China's Dalian University (Kumar 2018). Such training could have a long-term impact on China-Pacific military relations.

China has also increased its engagement with Pacific media, expecting outlets to portray a benign image of China to the public. This engagement is part of a move to 'tell China's stories well, present a true, multidimensional, and panoramic view of China', as envisaged by Xi Jinping when he addressed the 19th National Party Congress (Xinhua 2017). 
Since the establishment of a branch of China's official news agency, Xinhua, in Suva in September 2010 - the first in the Pacific-China has funded a growing number of Pacific journalists to visit China or attend professional training in China. For example, the MFA's Information Department organised tours for Pacific Island journalists in China in 2013 and 2017. Another delegation of Pacific media visited Beijing and Fujian Province (the main source of Chinese diaspora in Tonga) in 2015 at the invitation of the All-China Journalists' Association, an organisation led by the Chinese Communist Party. Yet, these efforts are compromised by other activities; in November 2018, Pacific journalists were denied entry to report on the meeting between leaders of China and Pacific states in Port Moresby in November 2018.

\section{Recent changes}

The Xi Jinping administration has been tightening the Chinese Communist Party's control on government policies including foreign policy. At the 19th Party Congress held in October 2017, which approved his second term, $\mathrm{Xi}$ announced that his administration would 'ensure Party leadership over all work' and 'the Party exercises overall leadership over all areas of endeavor in every part of the country' (Xinhua 2017), a lexicon used by former leader Mao Zedong during the Cultural Revolution. Although the Communist Party has already been leading Chinese foreign aid work, even more control could ensue in the future.

The newly established CIDCA will have a significant impact on Chinese aid to the Pacific. In March 2018, China's State Council announced the plan to establish this agency, which is designed to 'do overall planning and coordinating on major foreign aid issues, offer advice and advance the country's reforms in matters involving foreign aid ... identify major programs, supervise and evaluate implementation of such programs' (Y. Zhang 2018). The implementation of aid projects was left with the existing executing agencies. These include three agencies affiliated to MOFCOM: the Executive Bureau of International Economic Cooperation (responsible for complete projects—turnkey projects or chengtaoxiangmu, 成套项目—and technical cooperation projects); China International Centre for Economic and Technical Exchanges (responsible for in-kind donations); and the Academy for International Business Officials (responsible for training programs). Other line ministries such 
as the ministries of agriculture and education continue to provide foreign aid in their specialised areas. China Exim Bank remains responsible for concessional loans.

The Belt and Road Initiative (BRI) will be a significant factor in Chinese foreign aid in the region; indeed, CIDCA is largely designed to facilitate the implementation of BRI, a signature project of Xi Jinping and his diplomatic legacy. Xi has relentlessly promoted this initiative during his official meetings with leaders from other countries. As of January 2020, all 10 partner countries in the Pacific had signed up to BRI (see Table 2), with PNG the first in the region to sign on. In November 2018, cooperation under BRI featured in the bilateral and group meetings between $\mathrm{Xi}$ and Pacific leaders in Port Moresby, with incentives offered to attract Pacific states' participation in BRI. For example, Vanuatu and China signed the MOU on BRI cooperation on 9 November 2018; Xi then announced the MOU during his bilateral meeting with Vanuatu's Prime Minister, Charlot Salwai, a week later in Port Moresby. China also signed a further six agreements with Vanuatu, including economic and technical cooperation (grants provision); a framework for concessional loans; a protocol on debt relief; three MOUs on human resource development cooperation; exchanges between China's Guangdong Province and Vanuatu; and the establishment of a joint economic and trade commission between China's MOFCOM and Vanuatu's Ministry of Foreign Affairs (Vanuatu Daily Post 2018). Similarly, prior to the bilateral meeting between Xi and Cook Islands Prime Minister Henry Puna, China signed the MOU on BRI with Cook Islands and provided a grant of US $\$ 6.8$ million to the Pacific state (Radio New Zealand 2018).

BRI is even contributing to China's debt relief for Pacific countries. Tonga has linked its participation in BRI to the debt relief offered by China. On the margins of APEC in 2018, Tonga entered into BRI and received a five-year extension for repayment of debts owed to China. ${ }^{5}$ In stark contrast, Tonga's requests in recent years for debt relief had failed to gain any traction. Tonga's then prime minister, 'Akilisi Pohiva, had attempted to unify Pacific states to press Beijing for loan forgiveness and was openly mocked by Chinese official media, The Global Times, as a greedy move amounting to 'asking for the cow when milk is given' (Liu and Zhao 2018).

5 A similar five-year extension was granted in 2013. 
It is most likely that China will continue to frame its cooperation with PICs under BRI, as it has done in other regions-and Pacific states that extend more support to BRI could receive more Chinese aid.

Table 2. PICs signing up to the Belt and Road Initiative

\begin{tabular}{|c|c|}
\hline PICs & Time, Venue and Occasion \\
\hline PNG & $\begin{array}{l}\text { June } 2018 \text {, Beijing, during former prime minister Peter O'Neil's visit } \\
\text { to China. }\end{array}$ \\
\hline Niue & $\begin{array}{l}\text { July } 2018, \text { Niue, signed by the Chinese ambassador to New } \\
\text { Zealand (also accredited to Niue) and Prime Minister Sir Toke Talagi. }\end{array}$ \\
\hline Samoa & $\begin{array}{l}\text { September 2018, Beijing, during Prime Minister Tuilaepa } \\
\text { Malielegaoi's visit to China. }\end{array}$ \\
\hline FSM & $\begin{array}{l}\text { November 2018, Port Moresby, during the meeting between } \\
\text { former president Peter Christian and Chinese President Xi Jinping. }\end{array}$ \\
\hline Vanuatu & $\begin{array}{l}\text { November } 2018 \text {, Port Vila, signed by the Chinese ambassador } \\
\text { to Vanuatu and the Government of Vanuatu. }\end{array}$ \\
\hline Fiji & $\begin{array}{l}\text { November 2018, Suva, signed by the Chinese ambassador to } \\
\text { Fiji and the permanent secretary of the Office of the Prime Minister } \\
\text { of Fiji. }\end{array}$ \\
\hline Cook Islands & $\begin{array}{l}\text { November 2018, Wellington, signed by the Chinese embassy } \\
\text { in New Zealand with the Government of Cook Islands. }\end{array}$ \\
\hline Tonga & $\begin{array}{l}\text { November 2018, Port Moresby, during the meeting between former } \\
\text { prime minister 'Akilisi Pohiva and Chinese President Xi Jinping. }\end{array}$ \\
\hline Solomon Islands & $\begin{array}{l}\text { October } 2019 \text {, Beijing, during Prime Minister Manasseh Sogavare's } \\
\text { visit to China. }\end{array}$ \\
\hline Kiribati & $\begin{array}{l}\text { January 2020, Beijing, during President Taneti Maamau's visit } \\
\text { to China. }\end{array}$ \\
\hline
\end{tabular}

Source: Compiled by author.

A heightened geopolitical competition between traditional powers and China will also affect China's aid program in the Pacific. China's rise in the region has triggered grave concerns about China's intentions and the erosion of traditional powers' interests. In response, traditional powers have embarked on a mission to contain China's influence. In November 2017, the Trump administration introduced its Indo-Pacific strategy, which largely targets China. As part of the effort to implement the strategy, the US Government has merged its Overseas Private Investment Corporation and USAID's Development Credit Authority to facilitate provision of loans and compete with China in the infrastructure sector in developing countries. 
In Australia, both the Coalition Government and the opposition Australian Labor Party endorsed in 2019 a plan to provide loan facilities to Pacific Island states for infrastructure development. Similarly, the New Zealand Government is reenergising its regional approach and increasing technical and financial assistance to PICs. Clearly, these decisions have been taken in response to China's growing presence in the region. Powers outside the immediate region, such as Japan and India, are also devoting more resources to the Pacific amid China's rise. At the eighth Pacific Islands leaders meeting in May 2018, Japan committed US $\$ 515.8$ million (55 billion yen) to the region over three years, and funds for more than 5,000 Pacific Islanders through human resources development and people-to-people exchanges (Japan MOFA 2018). Although India's aid program is small in the Pacific, it is increasing notably. The Indian Government increased its annual grant aid to each of the 14 Pacific states from US $\$ 100,000$ to US $\$ 125,000$ in 2009, and further to US\$200,000 in 2014 (D. Zhang 2018:7). In November 2014 and April 2016, India also pledged two lines of credit, worth US\$75 million and US\$100 million, for Fiji and PNG respectively (ibid.).

In the near future, the dynamics of geopolitical competition in the Pacific coupled with China's growing strategic ambitions, could force China to increase its diplomatic and economic engagement with Pacific Island states to protect China's national interests. Geopolitical competition with traditional powers could gain more significance in China's diplomacy towards the region, making it another primary factor after the status of Taiwan. The weight of Pacific Island states in China's overall diplomacy could increase in the long term.

\section{Actors and their agency}

Actors involved in China's aid activities in the Pacific are active implementers. While their actions are shaped by China's bureaucratic structure and driven by their own interests, they also help define Chinese national interests and reshape the structure. The Party has the final say, but different ministries and other actors compete with each other for power and resources, and wield influence in aid policymaking and implementation. 
Competition between MOFCOM and MFA is prominent in this game. As the two most important ministries in China's aid program, their competition for control of Chinese aid resources has persisted since the 1950s when China started to provide foreign aid. In August 1952, China set up the Ministry of Foreign Trade, the predecessor of MOFCOM, to manage Chinese foreign aid, which was then mostly in the form of in-kind donations. Compared with MFA, the Ministry of Foreign Trade was in a better position to deliver aid because it could instruct its subordinate export and import companies to purchase materials for provision to recipient countries. From this point, MOFCOM remained the main custodian of the Chinese aid program until the establishment of CIDCA. Another reason for MOFCOM's control of Chinese aid is that former MOFCOM ministers were promoted to higher positions in the State Council or the Party than their counterparts from MFA. As a result, despite MFA's occasional proposals that it take control of the aid program, the central government has always ruled in MOFCOM's favour (Zhang and Smith 2017:2336).

Chinese embassies overseas, including in the Pacific, provide a new window to observe the subtle battle between MFA and MOFCOM on aid management. Normally the ambassadors are career diplomats selected within MFA. ${ }^{6}$ Officials in the Economic and Commercial Counsellor's office come from MOFCOM or subordinate agencies at provincial/ city levels. In principle, commercial officials need to receive the political leadership of the ambassador, report to the latter on aid issues and take into account his/her advice on aid delivery. Differences may arise, as commercial officials tend to consider economic benefits for China while the ambassador places greater weight on China's diplomatic interests. These two types of interests can be in conflict on some occasions. For example, provision of substantial loans to a resource-low country may not produce tangible economic returns for China, but is conducive to China's diplomatic objectives such as winning support for China on Taiwan or the South China Sea. Where such conflict arises, the Economic and Commercial Counsellor's office will wait for final instructions from MOFCOM rather than MFA, although MOFCOM and MFA may consult

6 In recent years, the Chinese Government has selected a growing number of senior officials from other ministries and provinces to serve as ambassadors in Chinese embassies overseas. In the Pacific, current Chinese ambassadors to Samoa and Vanuatu used to work in China’s Communist Youth League and Heilongjiang province respectively. The impact of non-MFA ambassadors on Chinese diplomacy and aid in the Pacific is unclear. 
each other in Beijing. Also, the commercial offices will report directly to MOFCOM and only copy MFA in. These offices in large countries have more budget and autonomy and have separate office buildings from the embassies. In the Pacific, China's Economic and Commercial Counsellor's office in PNG has its own office building.

Other line ministries in China have different organisational interests from those of MFA and MOFCOM. These ministries are responsible for aid delivery in their own areas and have specialised budgets, which represent a small proportion of Chinese total foreign aid spending. Their main interest is to deliver their aid to Pacific states well and maintain this business. Through providing foreign aid, the line ministries are keen to increase professional engagement with Pacific states in areas such as agriculture, health and education. For example, China's medical cooperation with PNG on malaria control presents an opportunity for Chinese experts to test and apply malaria technologies in a new environment. ${ }^{7}$ The implementation of line ministries' aid projects are shaped directly by the agency of the Chinese experts involved, as they are motivated by a variety of factors to work overseas. Some of the motives include a sense of glory as aid workers, economic benefits (the salary overseas is a few times higher), less family burden (for senior level experts), career bottleneck at home, and vision expansion ( $\mathrm{Lu}$ et al. 2015:17-18). The agency of these aid experts can be constrained by other factors. For example, the tenure for Chinese agricultural aid experts in the Pacific is normally two years, which is too short a period to gain familiarity with the local agricultural situation and apply their skills.

China Exim Bank has played a growing role in Chinese aid in the Pacific. Since 2006, concessional loans have become China's largest aid component in the region. The Chinese Government committed concessional loans to Pacific states to the value of US $\$ 463.1$ million (RMB3 billion) at the first China-Pacific Economic Development and Cooperation Forum in Fiji in April of that year, which marks the beginning of China's concessional loans to the region. A similar US $\$ 1$ billion loan facility was announced in November 2013. China Exim Bank officials on the ground enjoy plenty of autonomy on loan implementation. ${ }^{8}$ The bank has closer relations with MOFCOM than with MFA. The approaches of Exim Bank, MOFCOM and MFA to debt relief requests from recipient countries can also differ.

7 Chinese medical aid scholar and practitioner, August 2015. Interview with author.

8 Former Chinese aid official, July 2018. Interview with author. 
In recent years, the rapid growth of Chinese concessional loans in PICs has triggered debt-for-equity concerns-that is, that China may seek to control strategic assets in recipient countries when they default on loan repayment. MOFCOM and China Exim Bank, in particular the latter, require recipient countries to honour loan repayment. The careers of bank officials who approved the loans in the first place would be damaged if recipient countries defaulted on repayment. MFA officials, however, are inclined to support repayment extension or even loan forgiveness for the sake of China's bilateral relations with the recipient country. Currently, it is more likely that China will allow Pacific countries to postpone loan repayment rather than write the loans off.

The role of Chinese enterprises as aid contractors in the Pacific deserves greater analysis than is currently discussed in the literature. Chinese enterprises are attracted to the Pacific market, which is under-explored compared to other regions. State/province/city-owned enterprises have implemented Chinese aid projects in PICs and through those projects established themselves. Examples include the:

- China Civil Engineering Construction Corporation (Fa'onelua International Convention Centre in Tonga)

- China Rail First Group (Nabouwalu highway project in Fiji)

- China Harbor Engineering Company (National Capital District Commission road upgrade in Port Moresby)

- Guangdong Foreign Construction Company (University of Goroka dormitory project phase 2-4)

- China Jiangxi Corporation for International Economic and Technical Cooperation (International Convention Centre in Port Moresby).

Such companies operating in the Pacific receive political guidance from Chinese embassies. They engage principally with the Economic and Commercial Counsellor's office to whom they report. Companies working on Chinese concessional loan projects also need to report to China Exim Bank. In 2017, Economic and Commercial Counsellor's offices in the Pacific recorded a total of 53 Chinese enterprises operating in PNG, Fiji, Vanuatu, Tonga and FSM (see Table 3), with PNG home to the largest number of Chinese companies in the region. About 70 per cent of them are operating in the engineering/construction sector. 
Table 3. Sample of Chinese enterprises in the Pacific

\begin{tabular}{|l|l|l|}
\hline PIC & Total number & Breakdown by sectors \\
\hline PNG & 24 & $\begin{array}{l}\text { Engineering/construction: 17 } \\
\text { Building materials/equipment: 4 } \\
\text { Mining and metallurgy: 2 } \\
\text { Information technology: 1 }\end{array}$ \\
\hline Fiji & 12 & $\begin{array}{l}\text { Engineering/construction: } 6 \\
\text { Investment: 3 } \\
\text { Fisheries: 2 } \\
\text { Building materials/equipment: 1 }\end{array}$ \\
\hline Vanuatu & 11 & $\begin{array}{l}\text { Fishery: 6 } \\
\text { Information technology: 2 } \\
\text { Building materials/equipment: 1 } \\
\text { Manufacturing: 1 } \\
\text { Investment: 1 }\end{array}$ \\
\hline Tonga & 4 & $\begin{array}{l}\text { Engineering/construction: 3 } \\
\text { Manufacturing: 1 }\end{array}$ \\
\hline FSM & 2 & $\begin{array}{l}\text { Fisheries: 1 } \\
\text { Hotel: 1 }\end{array}$ \\
\hline
\end{tabular}

Note: This sample refers to Chinese companies registered with the Economic and Commercial Counsellor's offices in the Pacific. Data on Chinese companies in Samoa, Cook Islands and Niue is unavailable.

Source: Compiled by author from MOFCOM website data.

While commercial interest is the principal driver for Chinese enterprises, they have an impact on the Chinese aid system in three ways. First, in the past decade, a growing number of Chinese enterprises have moved into the Pacific, which forces the Chinese Government, especially MOFCOM, to devote more attention to the region. Second, these enterprises are contractors for the majority of Chinese aid projects. Their performance directly affects the implementation and image of China's aid. Project quality, cost and use of local labour are the main challenges. Substandard quality of construction has been found in some Chinese aid projects such as the Police, Justice and Sports complex in Cook Islands. Some Chinese contractors, such as China Harbour Engineering Company, have been slammed for inflating the project cost after they win the bidding with an intentionally lower quote. Insufficient use of local labour has provoked growing concerns about opportunities for the recipient countries. Chinese contractors do have agency on how to handle these concerns. In addition, there are complex relations between large Chinese state-owned enterprises, as the main contractor for Chinese aid projects, and other sub-contractor Chinese enterprises (see also Smith 2013), which often affect the progress of projects. 
Chinese contractors can also wield influence on Chinese aid through a bottom-up approach. By using their close relations with Pacific Island governments, Chinese enterprises, on some occasions, have actively pushed those governments to approach the Chinese Government to request aid. In this process, they use their local insight to provide assistanceranging from policy advice to project designs - to help these countries get the aid projects. As a reward, the Chinese enterprises then become the project contractors. Some contractors tend to bypass normal bureaucratic procedures in Pacific states and approach individual politicians, which breeds corruption.

\section{CIDCA}

The roles of MFA and MOFCOM in Chinese aid management are changing since the establishment of CIDCA in April 2018. As the Xi Jinping administration expects the Chinese aid program to play a more important role in supporting China's big power diplomacy and the BRI, MFA has been given greater power than MOFCOM in this new agency, which reports to Yang Jiechi and Wang Yi. Yang is director of the Party's Office of Foreign Affairs, the top decision-making organ overseeing China's diplomacy, and former minister of foreign affairs (April 2007 to March 2013). Wang is the incumbent Minister of Foreign Affairs (since March 2013) and State Councilor (vice premier level, since March 2018).

The change will have a significant impact on Chinese diplomacy in the Pacific and the competition between MOFCOM and MFA. To date, and compared with Africa and Asia, this competition in the Pacific has been less notable as most PICs are small and have limited natural resources except fisheries. For the most part, MFA has dominated the agenda due to the paramount importance of managing Taiwan in China's diplomacy in the region. However, foreign aid, which had been controlled by MOFCOM, is China's most important tool to gain support from Pacific states, which gives MOFCOM weight in this game. Foreign aid has dominated China's pledges to deepen China-Pacific cooperation since the visit of former premier Wen Jiabao in 2006 (coinciding with the first meeting of the China-Pacific Islands Economic Development and Cooperation Forum in April 2006), the second Forum meeting in November 2013 and the visit of President Xi Jinping in November 2014. 
However, with the creation of CIDCA, MFA and Chinese embassies in the Pacific will have more influence over Chinese aid. In particular, more aid projects will be framed within BRI. BRI dominated Xi Jinping's meetings (group meeting and bilateral meetings) with leaders of the eight PICs in November 2018, where Xi repeatedly called for Pacific states to focus on BRI cooperation. MFA's growing influence will also affect China's arrangement of debt payments for PICs as they need to start repaying Chinese concessional loans in the next few years. ${ }^{9}$ Relative to MOFCOM and China Exim Bank, the MFA will be more supportive of debt relief efforts in exchange for Pacific states' support of the One China policy and China's rise in the region. These efforts include the forgiveness of interestfree loans and extension of concessional loans, as the Tonga case suggests.

Embassy staffing also affects China's diplomacy and aid delivery in the Pacific. The Chinese ambassador to New Zealand is concurrently accredited to Cook Islands and Niue. China has resident embassies in PNG, Fiji, Vanuatu, Tonga, Samoa and FSM, and it will soon open embassies in Solomon Islands and Kiribati. There are more MFA officials working in the embassies than their counterparts from MOFCOM. The Economic and Commercial Counsellor's offices in China's embassies in PNG and Fiji have four staff each while the offices in Vanuatu, Tonga, Samoa and FSM have two staff each. Understaffing is a serious problem, as these officials need to work on trade, investment and aid. Moreover, trade and investment attract more of their attention as they have more weight than aid in the officials' annual performance evaluation.

The establishment of CIDCA will not solve understaffing unless more aid staff are allocated to the Economic and Commercial Counsellor's offices, which is unlikely in the near future, as these offices in other regions and CIDCA face similar, if not more serious, challenges. CIDCA has about 90 staff assigned from three sources. ${ }^{10}$ The primary source is MOFCOM's Department of Foreign Aid. The whole department of about 60 staff has relocated to CIDCA, except for a small number of retiring officials who preferred not to move. This is the largest concentration of aid technocrats in CIDCA. The second main source is MFA, where about 20 officials transferred to CIDCA of their own choice. China's National Development and Reform Commission is the third source with a small number of staff (mainly in the sections of personnel and logistics) moved to CIDCA with

9 The grace period is five to seven years.

10 Chinese aid official and scholar, July 2018. Interviews with author. 
Wang Xiaotao. Wang was a former deputy director of the commission and was appointed CIDCA's first director in April 2018. With Wang's extensive experience in policy planning and the commission's leading role in coordinating BRI among China's ministries, it is not surprising that CIDCA will largely focus on Chinese aid planning and BRI overseas, including in the Pacific.

CIDCA has three deputy directors. Zhang Maoyu is the most senior deputy director in rank. His appointment could be perceived as a political decision as his previous three-decade career in the China National Intellectual Property Administration is unrelated to Chinese aid or diplomacy. The other two deputy directors, Zhou Liujun and Deng Qingbo, have a strong background in China's Communist Youth League, a previously powerful party organisation that contributed a number of top echelon leaders, but the league's prominence has declined significantly in the Xi Jinping era. Between 2010 and 2018, Zhou was director-general of MOFCOM's Department of Trade in Services and Commercial Services and the Department of Outward Investment and Economic Cooperation. As CIDCA's deputy director, he will be likely to show strong interest in China's trade and investment activities in the Pacific. In contrast, Deputy Director Deng has nearly two decades of experience in the MFA since 2000. He was China's former ambassador to the Dominican Republic and Nigeria, and director-general of the Department of Party Related Affairs (also known as Department for Diplomatic Missions Overseas). Deng is likely to focus CIDCA's work in the Pacific more on China's diplomatic interests as identified by MFA.

The appointment of these senior officials as CIDCA's senior management reflect fierce competition between Chinese government agencies, especially MFA and MOFCOM for control of China's aid program, which is likely to continue. Wang Xiaotao's appointment as CIDCA director was a big surprise to many observers of Chinese aid and even MOFCOM officials. It could be interpreted as a compromise- a balance between MFA and MOFCOM interests. Internally, CIDCA has set up seven departments, focusing on general affairs, policy and planning, regional affairs (divided between two departments), supervision and evaluation, international cooperation, and party-related affairs (also in charge of personnel) (CIDCA 2018). This arrangement aligns with its intended objectives of prioritising Chinese aid planning and monitoring. 


\section{Conclusion}

Structure and agents are interdependent. This chapter analyses China's national interests in the Pacific, main actors and their nuanced interactions around Chinese diplomacy and aid in the Pacific region. As the discussion shows, China's national interests inform the work of these actors while the latter take agency to affect the structure. In particular, MFA and MOFCOM have competed to prioritise China's diplomatic and economic interests respectively. The creation of CIDCA will give MFA more influence in the formation of aid policy. The objective of support for China on Taiwan and the role of Pacific Island countries in Chinass overall diplomacy towards the developing world, as well as in China's geostrategic competition with traditional powers, could receive more attention from China in the future. The research also suggests that China will frame much of its aid program in the Pacific within the BRI.

Compared with previous administrations, the Xi Jinping administration has greater ambitions for China as a rejuvenating superpower in the world. China's diplomacy is becoming more proactive and assertive. China is expected to devote more resources to the Pacific, leaving China's mark and complicating regional dynamics. As traditional powers, such as the US and Australia, pledge to increase their engagement with Pacific states, more open competition between China and these powers is likely to take place in the region. This competition could motivate China to provide more aid to the region.

As a new agency, the impact of CIDCA on the Pacific, including in the sectors of Chinese aid planning, implementation and monitoring, needs to be observed into the future. How China and Pacific Island countries will develop their cooperation under the Belt and Road Initiative also deserves attention.

\section{References}

Brady, A. 2017. China as a Polar Great Power. New York: Cambridge University Press. doi.org/10.1017/9781316832004

Callahan, W. 2012. Sino-speak: Chinese Exceptionalism and the Politics of History. The Journal of Asian Studies 71(1):33-55. doi.org/10.1017/S00219 11811002919 
China International Development Cooperation Agency (CIDCA) 2018. Departments, 15 August. en.cidca.gov.cn/2019-08/02/c_262719.htm

China Ministry of Commerce (MOFCOM) 2015. Neishe jigou (Internal Structure). Department of Foreign Aid, MOFCOM, 30 June. yws.mofcom. gov.cn/article/gywm/201506/20150601028591.shtml

China Ministry of Foreign Affairs (MFA) 2018. China, Pacific Island Countries Lift Ties to Comprehensive Strategic Partnership. 16 November. www.fmprc. gov.cn/mfa_eng/zxxx_662805/t1615484.shtml

Erickson, A. and J. Wuthnow 2016. Barriers, Springboards and Benchmarks: China Conceptualizes the Pacific 'Island Chains'. The China Quarterly 225:1-22. doi.org/10.1017/S0305741016000011

Giddens, A. 1984. The Constitution of Society: Outline of the Theory of Structuration. Cambridge: Polity Press.

Gries, P.H. 2004. China's New Nationalism: Pride, Politics and Diplomacy. Berkeley: University of California Press.

Japan Ministry of Foreign Affairs (MOFA) 2018. The Eighth Pacific Islands Leaders Meeting (PALM8) Leaders' Declaration. www.mofa.go.jp/a_o/ocn/ page4e_000825.html

Kumar, A. 2018. First Navy Woman Gets Chinese Scholarship in the Officer Ranks. Fiji Sun, 11 September. fijisun.com.fj/2018/09/11/first-navy-womangets-chinese-scholarship-in-the-officer-ranks/

Liu, T. and J. Zhao 2018. Yao le niunai haiyao nainiu? Tang Jia shouxiang 'yao Beijing mianchu zhaiwu' tiyi tai ganga [Asking for the Cow After Milk Is Given? The Proposal of Tongan Prime Minister for China's Debt Relief is Embarrassing]. Global Times, 21 August. world.huanqiu.com/exclusive/201808/12778826.html

Lowy Institute 2019. Pacific Aid Map. pacificaidmap.lowyinstitute.org

Lu, J., Q. He and X. Li. 2015. Zhongguo yuanfei nongye zhuanjia paiqian xiangmu de kechixuxing chutan [A Feasibility Study on China's Dispatching of Agricultural Aid Experts to Africa]. World Agriculture (4):16-20.

Pacific Trade and Investment 2018. Trade Statistical Handbook 2017 between China and Forum Island Countries. Beijing: Pacific Trade and Investment Office.

Pedrozo, S.A. 2010. China's Active Defense Strategy and Its Regional Impact. Testimony Before the House of Representatives US-China Economic and Security Review Commission. New York: Council on Foreign Relations. www.cfr.org/ report/chinas-active-defense-strategy-and-its-regional-impact 
Pence, M. 2018. Remarks by Vice President Pence at the 2018 APEC CEO Summit, Port Moresby, Papua New Guinea. The White House, 16 November. china.usembassy-china.org.cn/remarks-by-vice-president-pence-at-the-2018apec-ceo-summit-port-moresby-papua-new-guinea/

People's Liberation Army Navy (PLAN) Party Committee 2018. Nuli ba renmin haijun quanmian jiancheng shijie yiliu haijun [To Strive to Develop the People's Navy into a World First-class Navy]. Qiushi Magazine, 31 May. www.qstheory. cn/dukan/qs/2018-05/31/c_1122897922.htm

Radio New Zealand 2018. China Grants Cook Islands \$US6.8 Million in Aid. 22 November www.radionz.co.nz/international/pacific-news/376532/chinagrants-cook-islands-us6-point-8m-in-aid

Smith, G. 2013. Beijing's Orphans? New Chinese Investors in Papua New Guinea. Pacific Affairs 86(2):327-49. doi.org/10.5509/2013862327

Vanuatu Daily Post 2018. 7 MOUs and Cooperation Agreements with China. 20 November. dailypost.vu/news/mous-and-cooperation-agreements-withchina/article_f2cb8ae5-fe7b-5ede-8683-fb263390917b.html

Wang, X. and F. Yu 2017. China Health Aid to the Pacific Island Countries. In Yu Changsen (ed.), Annual Report on Development of Oceania (2016-2017). Beijing: Social Sciences Academic Press (China):229-49.

Wendt, A. 1987. The Agent-Structure Problem in International Relations Theory. International Organization 41(3):335-70.

Wendt, A. 1992. Anarchy Is What States Make of It: The Social Construction of Power Politics. International Organization 46(2):391-425. doi.org/10.1017/ s0020818300027764

Wesley-Smith, T. 2013. China's Rise in Oceania: Issues and Perspectives. Pacific Affairs 86(2):351-72. doi.org/10.5509/2013862351

Xinhua 2017. Report Delivered at the 19th National Congress of the Communist Party of China. China Daily, 6 November. www.chinadaily.com.cn/interface/ flipboard/1142846/2017-11-06/cd_34188086.html

Yang, J. 2011. The Pacific Islands in China's Grand Strategy: Small States, Big Games. New York: Palgrave Macmillan. doi.org/10.1057/9780230339750

Zhang, D. 2017. China's Diplomacy in the Pacific: Interests, Means and Implications. Security Challenges 13(2):32-53. 
Zhang, D. 2018. China, India and Japan in the Pacific: Latest Development, Motivations and Impact. DPA Discussion Paper 2018/6. Canberra: ANU. dpa. bellschool.anu.edu.au/experts-publications/publications/6388/dp-201806china-india-and-japan-pacific-latest-developments

Zhang, D. and G. Smith 2017. China’s Foreign Aid System: Structure, Agencies, and Identities. Third World Quarterly 38(10):2330-346. doi.org/10.1080/ 01436597.2017 .1333419

Zhang, Y. 2018. New Agency to Guide Nation's Foreign Aid. China Daily, 14 March. www.chinadaily.com.cn/a/201803/14/WS5aa85af7a3106e7dcc1416dc.html 
This text is taken from The China Alternative: Changing Regional Order in the Pacific Islands, edited by Graeme Smith and Terence Wesley-Smith, published 2021 by ANU Press, The Australian National University, Canberra, Australia.

doi.org/10.22459/CA.2021.08 